\title{
DOES OWNERSHIP STRUCTURE MATTER FOR PUBLICLY LISTED COMPANIES PERFORMANCE IN MALAYSIA?
}

\section{Rozita Arshad}

Senior Lecturer, School of Government, College of Law, Government and International Studies, Universiti Utara Malaysia (UUM), Kedah, Malaysia. E-mail: roz@uum.edu.my

\begin{abstract}
The word of corporate governance has become a very important concept that requires many countries around the world to concentrate on its reformation. Globalisation of markets, open markets competition, and international business has generated awareness about the importance of improving corporate governance practices. Protecting shareholders and other stakeholders are also being attentive agenda and play important roles in corporate governance reforms due to ensure their value creation and their right as the owner of the shares. This article attempts to address this issue by examining the relationship between ownership structure and firm performance. The hypothesis is tested by assessing the impact of the structure of ownership on firm performance, using data for 237 Malaysia Public Listed Companies (PLCs). Therefore, this paper will provide an insight into further understanding on the issue of the relationship between ownership structure and firm performance
\end{abstract}

Keywords: Corporate governance, ownership structure, shareholders, firm performance

\section{Introduction}

Over the past decade, the term "corporate governance" has become an ordinary term by many level of people and there are now are more governance experts as compared to previous. The reformation of corporate governance has been believed can lead to better supervision and guidance of corporate behaviours (Iyengar, Williams \&Zampelli, 2005; Jensen \&Meckling, 1976). Better governance results from an improvement of the internal corporate governance mechanisms, carried out by the board of directors, audit committees, internal auditors, control and risk managements and external mechanisms including external auditors and also shareholder protection (Hasnah, 2009). As noted the large number of studies say that corporate governance can be used to improve responsibility, accountability and transparency of the companies that will in turn increase the long term investment and credibility to the companies (Armitage \& Marston, 2008; Holder-Webb, Cohen, Nath, \& Wood, 2008; Jongsureyapart, 2006; Koh, Laplante, \& Tong, 2007; Luo, 2005; Rueda-Sabater, 2000). International flow of investment and business requires that countries must decide if they will be involved in creating governance regulations or be governed in line with international requirements. Thus, corporate governance has become an international agenda item that affects the whole business world in order to develop good governance.

In today's uncertain economic times, shareholders demand more accountability from firm management. Indeed, individuals or investors will not simply invest in a firm without close involvement in ensuring their value creation is protected (Burnett, Xu, Morris and Rodriguez, 2012). Shareholders are becoming increasingly suspicious about directors' ability and willingness to protect their interests, especially after various media reports of corporate scandals due to the misuse of corporate funds. Most visibly, shareholder activism usually plays out via the use of resolutions (proposals) presented and acted upon at annual meetings (Burnett, et al., 2012). Most investors cared little about how a company was actually run as they focused more on how the company's stock performed despite 
the connection between the two (Romanek, 2011). As a result, shareholder activism over governance issues was practiced only by a few brave souls during the 20 the century. While most informed investors would define maximizing shareholder value as the primary task of the board of directors and senior management in every public company, this objective receives much less attention by the leadership of private companies (Evan and Bishop, 2002). It is not that they don't care about maximizing the company's value and their wealth. From our experience in working with hundreds of such executives and shareholders, we know that most care passionately.

According to Cadbury (2002) a basic debate on corporate governance arises from the conflict between the ownership of the companies (principal) and management (agent) has been highlighted by Berle and Means (1932) in their book The Modern Corporation and Private Property, which documented the existence of a "separation of ownership from control". The book has generated numerous studies that hypothesized the nature of the conflict between owners (shareholders) and managers. The separation of ownership from management had resulted in shareholders being unable to exercise any control over boards of directors, who are theoretically appointed by them to represent their interests.

\section{Ownership Structure}

The polarisation of ownership structure arises from differences that exist between the cultures and legal systems of countries (Claessens et al., 2000; Guay, 2002). These differences have created two ownership structure systems: the insider-dominated ownership structure (concentrated shareholding); and, the outsider-dominated ownership structure (Anglo-Saxon world competitive)(La Porta et al., 1999; Solomon \& Solomon, 2004). Asian countries like Malaysia, the Republic of Korea, Indonesia, Thailand, Hong Kong and Taiwan are characterised by the insiderdominated ownership structure (Claessens, Djankov, \& Lang, 2000; Johnson et al., 2000; Nam \& Nam, 2004; Thillainathan, 1999). Table 1 summarises the characteristics of each ownership structure and the legal systems.

Table 1: Characteristic of ownership structure and legal systems

\begin{tabular}{|l|l|}
\hline \multicolumn{1}{|c|}{$\begin{array}{c}\text { Insider-dominated ownership structure } \\
\text { (concentrated shareholding) }\end{array}$} & \multicolumn{1}{|c|}{$\begin{array}{c}\text { Outsider-dominated ownership structure } \\
\text { (dispersed shareholding) }\end{array}$} \\
\hline $\begin{array}{l}\text { Firms owned predominantly by insider } \\
\text { shareholders who also control management }\end{array}$ & $\begin{array}{l}\text { Large firms controlled by managers but owned } \\
\text { predominantly by outside shareholders }\end{array}$ \\
\hline $\begin{array}{l}\text { System characterised by little separation of } \\
\text { ownership and control thus, agency problems are } \\
\text { rare }\end{array}$ & $\begin{array}{l}\text { System characterised by separation of ownership and } \\
\text { control, which engenders significant agency problems }\end{array}$ \\
\hline Hostile takeover activity is rare & $\begin{array}{l}\text { Frequent hostile takeovers acting as a disciplining } \\
\text { practice on company management }\end{array}$ \\
\hline $\begin{array}{l}\text { Concentration of ownership in a small group of } \\
\text { shareholders (founding family members, other } \\
\text { firms through pyramidal structures, state } \\
\text { ownership) }\end{array}$ & Dispersed ownership \\
\hline $\begin{array}{l}\text { Excessive control by a small group of "insider" } \\
\text { shareholders }\end{array}$ & Moderate control by a large range of shareholders \\
\hline $\begin{array}{l}\text { Wealth transfer from minority shareholders to } \\
\text { majority shareholders }\end{array}$ & $\begin{array}{l}\text { No transfer of wealth from minority shareholders to } \\
\text { majority shareholders }\end{array}$ \\
\hline Weak investor protection in company law & Strong investor protection in company law \\
\hline $\begin{array}{l}\text { Potential for abuse of power by majority } \\
\text { shareholders }\end{array}$ & Potential for shareholder democracy \\
\hline $\begin{array}{l}\text { Majority shareholders tend to have more "voice" } \\
\text { in their investee firms. }\end{array}$ & $\begin{array}{l}\text { Shareholding characterised more by "exit" than by } \\
\text { "voice" }\end{array}$ \\
\hline Sorre (Solon \& Som, &
\end{tabular}

Source: (Solomon \& Solomon, 2004) 
According to Fazilah (2002), the ownership structure determines the nature of the agency problem, whether the dominant conflict is between managers and shareholders, or between controlling and minority shareholders. In the Malaysian PLCs scenario, the level of ownership concentration is high, which gives strength to the dominant shareholders (Thillainathan, 1999). The dominant shareholders may act in their own interest by utilising the minority wealth (funds). The protection for minority shareholders against expropriation by dominant shareholders is very low which can increase agency problems (Claessens et al., 1999; Fazilah, 2002; Shleifer\&Vishny, 1997). Therefore, it is expected that the concentrated ownership structure tend to increase agency problem.

According to Larcker, Richardson and Tuna (2004), the definition of ownership relies on the fraction of outstanding shares held by an individual or group. The MCCG 2000 defines ownership (shareholder) based on an effective communication policy in the firms which allows shareholders to be involved in decision-making through voting rights and AGMs. Shareholding in Malaysian Publicly Listed Companies (PLCs) is concentrated and dominated by the family (Thillainathan, 1999). The next important categories of dominant shareholders by rank are the state, corporations and financial institutions. However, the empirical survey by Nam and Nam (2004) indicates that the majority of Malaysian companies belong to private business groups or corporations. Both studies indicate the change of ownership trend from concentrated dominated by family to business groups in Malaysian Publicly Listed Companies between 1999 and 2004.

Zuaini (2004, pp. 45-48) divided ownership structure into two categories, based on the control or voting rights and the cash flow rights (ownership): 1) control rights are equal to cash flow rights (referred to as large ownership); and, 2) control rights are above cash flow rights (referred to as ultimate ownership). Basically, individual shareholders in companies/corporations that have widely dispersed ownership do not have sufficient incentives to monitor the behaviour of the manager. They rely on managers to run the business or to control the cash flow (Shleifer\&Vishny, 1997). According to Zuaini (2004, p. 45), greater concentrations of ownership will lead to effective alignment of management and shareholders' interests and result in higher performance. However, too concentrated ownership has been argued to reduce monitoring and let the dominant ownership exercise control for their benefit (Shleifer\&Vishny, 1997). This transfers the agency problem away from the conflict between managers and shareholders, to the conflict between controlling shareholders (large shareholder and manager) and minority shareholders (Fan \& Wong, 2002). This situation can create a serious loss of efficiency and expropriation of minority shareholders who do not participate in management and who are not a controlling shareholder.

\section{Ownership Structure and Firm Performance}

Numerous studies have analysed the link between ownership structure and firm performance. An empirical study by Demsetz and Lehn (1985) found no significant correlation between ownership concentration and profit rates for 511 large corporations. There is also a study which shows that higher ownership concentration leads to detrimental effects for corporations as large block holders and managers can collude to extract rents from small shareholders (Lehman \&Weigand, 2000). Morck, Shleifer and Vishny (1988) discovered a non-monotonic relation between Tobin's Q and insider ownership. Increasing insider ownership between $0 \%$ and $5 \%$ has positive impact on Tobin's Q. The effect is reversed for insider control over $5 \%$ to $25 \%$ of the voting rights, and it is again positively related to $\mathrm{Q}$ if management holds more than $25 \%$ of the equity. It seems that at low levels of insider ownership, the agency costs decrease. While with rising insider ownership and higher levels of insider control, agency costs increase but the management can maximise shareholder value.

Joh (2003) analysed ownership structures and conflicts of interest among shareholders under a poor corporate governance system in Korea affected firm performance before the financial crisis (1993-1997). They found that firms with low ownership concentration show low firm profitability, controlling for firm and industry characteristics, and firms with a high disparity between control rights and ownership rights showed low profitability.Kapopoulos, and Lazaretou, (2007) in their study among 175 Greek listed firms found that ownership structure (managerial shareholdings and important shareholdings) is positively influence Tobin's Q. The results suggest that the greater the degree to which shares are concentrated in the hands of outside or inside shareholders, the more effectively management behaviour is monitored and disciplined, thus resulting in better performance.

Ming, Gee and Lee (2006) examined the impact of ownership structure on the corporate performance of Malaysian public-listed companies from 2002 to 2004. They found that the presence of insider and institutional equity 
shareholdings do not provide an association with corporate performance. The results suggest that institutional shareholders failed in their monitoring role and the introduction of the corporate governance standards (MCCG 2000) had also failed to influence shareholder value creation. Roszaini and Hudaid(2006) investigated the relationship between the corporate governance structure and performance in 347 Malaysia public listed companies in between 1996 and 2000. They found board size and top five substantial shareholdings to be significantly associated with both market and accounting performance measures. Tam and Tan added (2007, p. 208) that the protection of shareholders' rights is a main issue in Malaysia because the large shareholders will dominantly control via ownership concentration and representation on company board and management. Based on data of Malaysia's top 150 publicly listed firms, Tam and Tan (2007) found that governance practices such as adopting concentrated ownership and CEO-Chairman duality have affected firm performance. From the above discussion and prior literature, therefore the following hypotheses are stated as follows:

\section{$H 1=$ Changes in shareholder structure are positively associated with changes in firm performance.}

\section{Methodology}

This study focuses on the ownership structure and firm performance of the publicly listed companies ${ }^{1}$ on the Main and Second Board of Bursa Malaysia (KLSE) in 1996 to 2008. A Pearson correlation analysisand multivariate regression analysis are conducted to empirically test the formulated hypothesis. The population of the research involves all the 'Main Board' and the 'Second Board' of the Publicly Listed Companies (PLCs) in the Bursa Malaysia (formerly known as the Kuala Lumpur Stock Exchange), with the exception of the companies listed in the MESDAQ Market. Non-probably convenience sampling was employed in this research because the nature of the study requires only the companies that available with information about each director of the companies. A total of 237 companies were identified to meet with the criteria.

For accounting based measures, earning per share (denoted as EPS), return on assets (denoted as ROA) and return on equity (denoted as ROE) are used alternatively. EPS is calculated as earnings based on average common shares for the 12 months ended the last financial year, which is generated from DataStream. ROA and ROE are purely accounting based measures (profit ratios) and were computed from company financial statement data. The ROA is a useful measurement to indicate the profit of the company relative to total assets (Jong 2003). ROA rationally indicates management's/company's effectiveness in utilising the assets entrusted to them and does not depend on the alternative uses of debt versus equity to fund such assets (Robinson, 1998). Similar to ROA, ROE indicates management's effectiveness in generating a return on the funds invested by the common shareholders, to whom management is ultimately responsible and accountable. For this study, the ROA and ROE were generated from DataStream data. The ROA and ROE are calculated based on the following formula:

ROA $=\frac{(\text { After tax profit })_{\mathrm{t}}}{(\text { Total assets })_{\mathrm{t}-1}}$
Where,
Preferred dividend requirement $=\quad \begin{aligned} & \text { Actual cash dividend payment on preferred stock or the provision } \\ & \text { for preferred dividends, if in arrears. It also includes accretion on } \\ & \text { preferred stock. }\end{aligned}$

\footnotetext{
${ }^{1}$ Companies been listed in the Bursa Malaysia are either listed on 1) Bursa Malaysia Securities Main Board for larger capitalised companies, 2)
} the Second Board for the medium sized companies, or 3) the MESDAQ Market for high growth and technology companies. 
Ownership structure is measured based on eight variables as follows: 1) number of family member owning shares in the company (SHFAMSZ); 2) number of director owning shares in the company (SHDIRSZ); 3) number of private institutions or companies owning shares in the company (SHINTSZ); 4) number of activist institutions owning shares in the company (SHACTSZ); 5) disclosure of effective communication with shareholders through company proxies (SHCOMM); and 6) disclosure of annual general meeting held (SHAGM).

Multivariate regression models:

$$
\Delta \mathrm{FP}_{i,}=\beta_{0}+\beta_{1} \Delta \mathrm{SHAGM}_{i}+\beta_{2} \Delta \mathrm{SHCOMM}_{i}+\beta_{3} \Delta \text { SHFAMSZ }_{i}+\beta_{4}
$$

Where

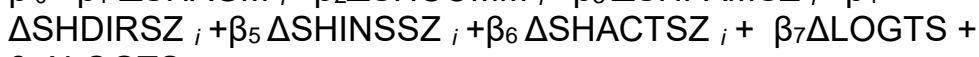
$\beta_{8} \Delta$ LOGTS $+\varepsilon_{i}$

$\triangle \mathrm{FP} i, \quad=$ The change in firm performance (EPS, ROE, ROA, RET and RETadj)

$\triangle$ SHFAMSZ = Change in the mean number of family members holding shares in the PLCs.

$\triangle$ SHDIRSZ = Change in the mean number of director owned shares in the PLCs.

$\triangle$ SHINSSZ = Change in the mean number of institution (private companies) owned shares in the PLCs.

$\triangle$ SHACTSZ $=$ Change in the mean number of activist institution owned shares in the PLCs.

$\triangle$ SHCOMM = Change in the mean of disclosure about the PLCs has communication with shareholders.

$\triangle$ SHAGM = Change in the mean of disclosure about the PLCs has held an AGM.

${ }^{*} \triangle \mathrm{LOGTA} \quad=$ Change in the mean of total assets

${ }^{*} \triangle$ LOGTS $=$ Change in the mean of net sales

Notes: * Control variables

\section{Results}

The Pearson correlation coefficients in Panel A, Table 2 show that among all the variables, only $\Delta$ LOGTSand $\Delta$ EPS is significantly positively correlated $(\mathrm{r}=0.188)$ at the 0.01 level. This positive correlation provides limited evidence that an increase in the firm size is associated with an increase in this particular measure of firm performance.

Table 2: Correlation coefficients and regression estimates for changes in shareholders structure variables and changes in firm performance for 237 PLCs.

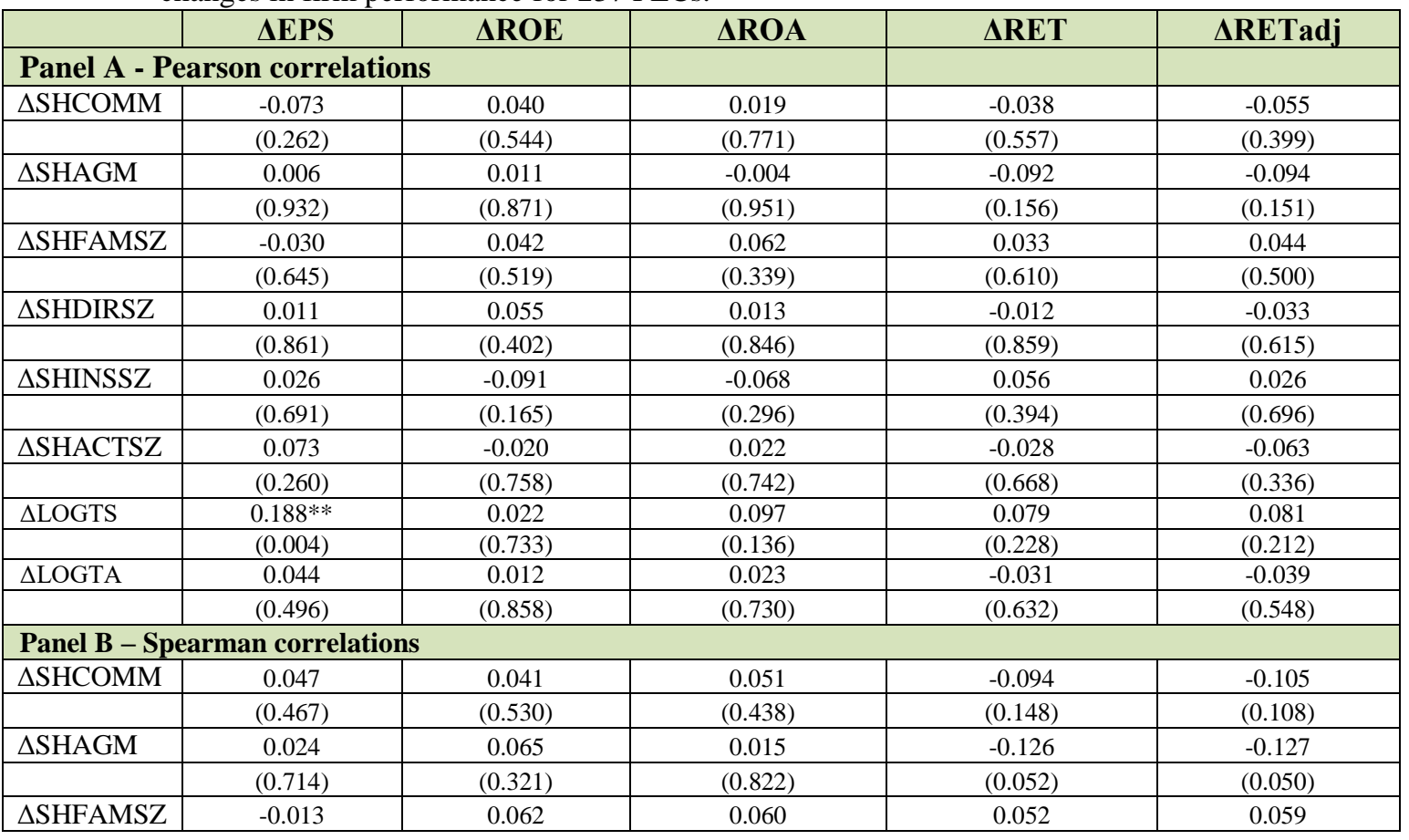




\begin{tabular}{|c|c|c|c|c|c|c|c|c|c|c|}
\hline & \multicolumn{2}{|c|}{$(0.847)$} & \multicolumn{2}{|c|}{$(0.343)$} & \multicolumn{2}{|c|}{$(0.357)$} & \multicolumn{2}{|c|}{$(0.425)$} & \multicolumn{2}{|c|}{$(0.367)$} \\
\hline$\Delta$ SHDIRSZ & \multicolumn{2}{|c|}{0.095} & \multicolumn{2}{|c|}{0.055} & \multicolumn{2}{|c|}{0.033} & \multicolumn{2}{|c|}{0.002} & \multicolumn{2}{|c|}{-0.007} \\
\hline & \multicolumn{2}{|c|}{$(0.146)$} & \multicolumn{2}{|c|}{$(0.402)$} & \multicolumn{2}{|c|}{$(0.614)$} & \multicolumn{2}{|c|}{$(0.970)$} & \multicolumn{2}{|c|}{$(0.911)$} \\
\hline$\Delta$ SHINSSZ & \multicolumn{2}{|c|}{0.100} & \multicolumn{2}{|c|}{0.008} & \multicolumn{2}{|c|}{0.012} & \multicolumn{2}{|c|}{0.054} & \multicolumn{2}{|c|}{0.038} \\
\hline & \multicolumn{2}{|c|}{$(0.125)$} & \multicolumn{2}{|c|}{$(0.903)$} & \multicolumn{2}{|c|}{$(0.854)$} & \multicolumn{2}{|c|}{$(0.411)$} & \multicolumn{2}{|c|}{$(0.564)$} \\
\hline$\triangle$ SHACTSZ & \multicolumn{2}{|c|}{0.101} & \multicolumn{2}{|c|}{-0.007} & \multicolumn{2}{|c|}{0.019} & \multicolumn{2}{|c|}{-0.015} & \multicolumn{2}{|c|}{-0.040} \\
\hline & \multicolumn{2}{|c|}{$(0.120)$} & & & & & & & & \\
\hline$\Delta$ LOGTS & & $24 * *$ & 0.1 & & & & & & & \\
\hline & & 000) & $(0$. & & & & & & & \\
\hline$\Delta$ LOGTA & & $10 * *$ & -0. & & & & & & & \\
\hline & & 001) & $(0$. & & & & & & & \\
\hline Panel C- Or & nary I & ast Squa & Regress & & & & & & & \\
\hline & & del a & & & & lel c & & el d & & $\mathrm{el} \mathrm{e}$ \\
\hline & $\beta$ & $t$-value & $\beta$ & $t$-value & $\beta$ & $t$-value & $\beta$ & $t$-value & $\beta$ & $t$-value \\
\hline (Constant) & $\begin{array}{c}- \\
0.379 \\
\end{array}$ & $(0.705)$ & -0.828 & $(0.408)$ & -3.032 & $(0.003)$ & -7.540 & $(0.000)$ & -9.833 & $(0.000)$ \\
\hline$\triangle \mathrm{SHCOMM}$ & $\begin{array}{c}- \\
1.482\end{array}$ & $(0.140)$ & 0.461 & $(0.645)$ & 0.124 & $(0.902)$ & -0.153 & $(0.878)$ & -0.460 & $(0.646)$ \\
\hline$\triangle$ SHAGM & 0.698 & $(0.486)$ & 0.017 & $(0.986)$ & -0.034 & $(0.973)$ & -1.290 & $(0.198)$ & -1.223 & $(0.223)$ \\
\hline$\triangle$ SHFAMSZ & $\begin{array}{c}- \\
0.469 \\
\end{array}$ & $(0.640)$ & 0.665 & $(0.507)$ & 0.930 & $(0.353)$ & 0.576 & $(0.565)$ & 0.710 & $(0.479)$ \\
\hline$\Delta$ SHDIRSZ & $\begin{array}{c}- \\
0.018 \\
\end{array}$ & $(0.985)$ & 0.948 & $(0.344)$ & 0.257 & $(0.797)$ & -0.079 & $(0.937)$ & -0.334 & $(0.739)$ \\
\hline$\Delta$ SHINSSZ & 0.257 & $(0.797)$ & -1.419 & $(0.157)$ & -1.033 & $(0.302)$ & 0.734 & $(0.463)$ & 0.174 & $(0.862)$ \\
\hline$\triangle$ SHACTSZ & 1.125 & $(0.262)$ & -0.625 & $(0.533)$ & 0.052 & $(0.958)$ & -0.374 & $(0.709)$ & -0.969 & $(0.333)$ \\
\hline$\Delta$ LOGTS & 2.897 & $(0.004)$ & 0.390 & $(0.697)$ & 1.496 & $(0.136)$ & 1.246 & $(0.214)$ & 1.390 & $(0.112)$ \\
\hline$\Delta$ LOGTS & 0.090 & $(0.928)$ & -0.001 & $(0.999)$ & 0.015 & $(0.988)$ & -0.679 & $(0.498)$ & -0.767 & $(0.444)$ \\
\hline Adjusted R & & 17 & & & & 16 & & & & \\
\hline F statistic & & 523 & & & & & & & & \\
\hline
\end{tabular}

* Significant at the 0.05 level, ** Significant at the 0.01 level

$\triangle \mathrm{SHCOMM}=$ Change in the mean extent of disclosure that the PLCs have communication with shareholders.

$\triangle$ SHAGM $=$ Change in the mean extent of disclosure that the PLCs have held an AGM.

$\Delta$ SHFAMSZ $=$ Change in the mean extent of disclosure about the number of family members holding shares in the PLCs.

$\Delta$ SHDIRSZ $=$ Change in the mean extent of disclosure about the number of director owned shares in the PLCs.

$\Delta$ SHINSSZ $=$ Change in the mean extent of disclosure about the number of institution (private companies) owned shares in the PLCs.

$\triangle \mathrm{SHACTSZ}=$ Change in the mean extent of disclosure about the number of activist institution owned shares in the PLCs.

$\triangle$ LOGTS $=$ Change in the mean total sales.

$\triangle$ LOGTA $=$ Change in the mean total assets.

Panel B shows the Spearman correlation coefficients. Among all the variables, six significant correlations exist as follows: 1) $\triangle$ LOGTS and $\triangle$ EPS $(\mathrm{r}=0.324) ; 2) \Delta$ LOGTS and $\triangle \mathrm{ROA}(\mathrm{r}=0.150) ; 3) \Delta \mathrm{LOGTS}$ and $\Delta \mathrm{RET}(\mathrm{r}=0.189) ; 4)$ $\Delta$ LOGTS and $\triangle$ RETadj $(\mathrm{r}=0.197) ; 5) \Delta$ LOGTA and $\triangle$ EPS $(\mathrm{r}=0.210)$; and 6$) \Delta$ LOGTA and $\Delta$ RETadj $(\mathrm{r}=0.132)$. All variables are significantly positively correlated at the 0.01 and 0.05 levels. This positive correlations provide evidence that an increase in firm size (LOGTS and LOGTA) is associated with the increase in the both accounting based measures (EPS, ROE and ROA) and market based measures (RET and RETadj). Therefore, bigger firm size has better firm performance.

Panel $\mathrm{C}$ shows the results obtained from regressing changes in firm performance on the changes in shareholders structure variables. The results indicate that none of the models (, b, c, d or e) are significant. However, only 
$\Delta$ LOGTS ( $\mathrm{t}=2.897)$ is positively and significantly associated with $\triangle \mathrm{EPS}$ at the 0.01 level. This result provides some additional support for a positive relationship between changes in EPS and the firm size.

Overall, the correlation and regression results do not provide strong support for hypothesis H1. Most changes in shareholders structure that increase compliance with the MCCG 2000 are not significantly associated with changes in firm performance. However, consistent support was found for a significant positive relationship between changes in the firm size (LOGTS) and the changes in one accounting based measure of firm performance, EPS. Due to the positive relation between firm size and firm performance, this suggests that larger PLCs have higher firm performance

\section{Discussion and Conclusions}

This study has analysed the relationship of ownership structure and firm performance. Hypothesis 1 was tested by regressing changes in firm performance variables due to changes in shareholder structure variables. Similarly, the regression results provide that none of the models are significant. Only very limited evidence on the significant relationship between changes in firm size ( $\triangle$ LOGTS) and changes in firm performance, EPS are found. This result suggests that larger PLCs have higher firm performance. This result provides very limited support for the hypothesis. Therefore, the results indicate that hypothesis 1 is not supported.

This finding is in line with several prior studies, which also found that some shareholder structures were not significantly associated with firm performance. Demsetz and Lehn (1985) found no evidence for a relationship between the profit rate and the ownership concentration. Chang and Shin (2006) found no relationship between controlling family ownership and firm performance. Zeitun and Tian (2007) found that ownership concentration measured by HERF index (the sum of squared percentage of shares controlled by each top five shareholders) is not significant with firm performance.

However, there are some inconsistencies between the results of this study and several earlier studies. The following ownership (shareholder) structure has been found to be significantly associated with measures of firm performance: ownership concentration (Céspedes, González, \& Molina, 2010; Joh, 2003; Margaritis\&Psillaki, 2010; Zeitun\& Tian, 2007), insider/managerial ownership (Agrawal \&Knoeber, 1996; Bauguess et al., 2009; McConnell \&Servaes, 1990, 1995), block ownership (Patro, 2008), outsider ownership (Bauguess et al., 2009), voting power (Attig et al., 2008), and large or controlling shareholder (Attig et al., 2008; Volpin, 2002). These inconsistent results are probably caused by the different scopes and methods used. Therefore, there are inconclusive and mixed results in the literature between the shareholder structure and firm performance.

\section{Bibliography}

1. Armitage, S., \& Marston, C. (2008). Corporate disclosure, cost of capital and reputation:

Evidence from finance directors. The British Accounting Review, 40(4), 314-336.

2. Burnett, R.D., Xu, L., Morris, M. \& Rodriguez, Jr. R. P., (2012). Shareholder activism targets M\&As, The Journal of Corporate Accounting \& Finance, 23 (2), p. 9-20.

3. Burnett, R.D., Xu, L., Morris, M. \& Rodriguez, Jr. R. P., (2012). Shareholder activism targets M\&As, The Journal of Corporate Accounting \& Finance, 23 (2), p. 9-20.

4. Cadbury, A. (2002). Corporate Governance and Chairmanship: A Personal View (Publication. Retrieved March 2006: http://library.books24x7.com.ezproxy.usq.edu.au/book/id 6181/viewer.asp?bookid=6181\&chunki $\underline{\mathrm{d}=0532599911}$ 
5. Céspedes, J., González, M., \& Molina, C. A. (2010). Ownership and capital structure in Latin America. Journal of Business Research, 63(3), 248-254.

6. Claessens, S., Djankov, S., \& Lang, L. H. P. (2000). The separation of ownership and control in East Asian Corporations. Journal of Financial Economics, 58(1-2), 81-112.

7. Claessens, S., Djankov, S., Fan, J. P. H., \& Lang, L. H. P. (2002). Disentangling the incentive and entrenchment effects of large shareholdings. Journal of Finance, LVII(6), 2741-2771

8. Conyon, M. \& Sadler, G., (2010).Shareholder voting and directors'remuneration report legislation: Say on pay in the UK, Corporate Governance: An International Review, 18(4) 296312

9. Evan, F. C. \& Bishop, D. M., (2002). Managing your business as an investment: How to build shareholder value in in private companies, The Journal of Corporate Accounting \& Finance, 23 (2), pg 49-59

10. Evan, F. C. \& Bishop, D. M., (2002).Managing your business as an investment: How to build shareholder value in in private companies, The Journal of Corporate Accounting \& Finance, 23 (2), pg 49-59

11. Fan, J. P. H., \& Wong, T. J. (2002).Corporate ownership structure and the informativeness of accounting earnings in East Asia. Journal of Accounting and Economics, 33, 401-425.

12. Fan, J. P. H., \& Wong, T. J. (2005). Do External Auditors Perform a Corporate Governance Role in Emerging Markets? Evidence from East Asia. Journal of Accounting Research, 43(1), 35-72.

13. Fazilah, A. S. (2002). Ownership structure in the Malaysian corporation sector: Its impact on corporate governance performance, financing and investment patterns. Retrieved 30.03.2006

14. Hasnah, H. (2009). Corporate governance failure: How would effective internal and external monitoring mechanisms help?Pulau Pinang: Penerbit Universiti Sains Malaysia.

15. Holder-Webb, L., Cohen, J., Nath, L., \& Wood, D. (2008).A survey of governance disclosures among U.S. firms. Journal of Business Ethics, 83, 543-563.

a. lyengar, R. J., \&Zampelli, E. M. (2008).Auditor independence, executive pay and firm performance.Accounting \& Finance, 48(2), $259-278$

16. Jensen, M., \&Meckling, W. (1976). Theory of the firm: managerial behaviour, agency cost and ownership structure. Journal of Financial Economics, 3(305-360).

17. Joh, S. W. (2003). Corporate governance and firm profitability: evidence from Korea before the economic crisis. Journal of Financial Economics, 68(2), 287-322.

18. Jongsureyapart, C. (2006). Factors that determine corporate governance in Thailand. Unpublished Research Ph.D, Victoria University, Melbourne

19. Kapopoulos, P., \&Lazaretou, S., (2007). Corporate ownership structure and firm performance: evidence from Greek firms, Corporate Governance15 (2), pg. 144-158

20. Koh, P.-S., Laplante, S. K., \& Tong, Y. H. (2007).Accountability and value enhancement roles of corporate governance. Accounting \& Finance, 47, 1-29.

21. La Porta, R., Lopez-de-Silanes, F., \&Shleifer, A. (1999). Corporate ownership around the world. The Journal of Finance, LIV(2), 471-517. 
22. La Porta, R., Lopez-de-Silanes, F., Shleifer, A., \&Vishny, R. (1998). Law and finance.Journal of Political Economy, 106, 1115-1155.

23. Larcker, D. F., Richardson, S. A., \& Tuna, I. (2007).Corporate governance, accounting outcomes, and organizational performance. The Accounting and Review, 82(4), 963-1008.

24. Lehman, E., \&Weigand, J. (2000). Does the governed corporation perform better? Governance structures and corporate performance in Germany. European Finance Review, 4, 157-195

25. Luo, Y. (2005). How does globalisation affect corporate governance and accountability? A perspective from MNEs. Journal of International Management, 11, 19-41.

26. Margaritis, D., \&Psillaki, M. (2010). Capital structure, equity ownership and firm performance. Journal of Banking \& Finance, 34(3), 621-632.

27. Ming, J. T. C., Gee, C. S., \& Lee, C. L. (2006). Ownership structure and corporate governance: further evidence from Malaysia. Banker's Journal Malaysia (130), 21-32.

28. Nam, S.-W., \& Nam, C. (2004).Corporate governance in Asia: recent evidence from Indonesia, Republic of Korea, Malaysia, and Thailand. Tokyo: Asian Development Bank Institute.

29. Roche, J. (2005). Corporate governance in Asia. New York: Routledge.

30. Romanek, B., (2011). The pioneers of corporate governance, The Corporate Governance Advisor, 19 (6), pg 1-6

31. Romanek, B., (2011). The pioneers of corporate governance, The Corporate Governance Advisor, 19 (6), pg 1-6

32. Shleifer, A., \&Vishny, R. W. (1986).Large shareholders and corporate control. Journal of Political Economy, 94(3), 461-488.

33. Shleifer, A., \&Vishny, R. W. (1997).A survey of corporate governance. Journal of Finance, 52(2 (June)), 737-768.

34. Shleifer, A., \&Wolfenzon, D. (2002).Investor protection and equity markets. Journal of Financial Economics, 66(1), 3-27.

35. Solomon, J., \& Solomon, A. (2004). Corporate governance and accountability. West Sussex: John Wiley \& Sons Ltd.

36. Thillainathan, R. (1999). Corporate governance \& restructuring in Malaysia: a review of markets, mechanisms, agents and the legal infrastructure. Kuala Lumpur: World bank/OECD Survey of Corporate Governance.

37. Zeitun, R., \& Tian, G. G. (2007). Does ownership affect a firm's performance and default risk in Jordan? Corporate Governance, 7(1), 66-82.

38. Zuaini, I. (2004). Corporate boards, ultimate ownership structure and corporate diversification: a study of public listed companies in Malaysia Unpublished PhD, University of Southampton, Souththampton. 